\title{
COLONIAL POLITICS IN FORMING ETHNIC IDENTITY OF MELAYU MINANGKABAU AND BATAK IN TAPANULI
}

\author{
Ida Liana Tanjung ${ }^{1}$, Bambang Purwanto ${ }^{2}$, Nur Aini Setiawati ${ }^{2}$ \\ ${ }^{1}$ History Education Department, Faculty of Social Science, Universitas Negeri Medan \\ ${ }^{2}$ History Department, Faculty of Social Science, Universitas Gadjah Mada \\ Email: idaliana.tanjung@mail.ugm.ac.id
}

\begin{abstract}
The article discusses the forming of ethnic identity among Batak and Malay people in Tapanuli during colonial period. The colonial government that desired to expand its hegemony among these ethnic groups had led them to create policies and boundaries for the groups in Tapanuli. This study uses historical method (heuristic) that begins from sources collection, sources critique, interpretation and explanation. Constructive approach is used to analyze the sources that considers ethnic identity is a result of construction process of a particular group. This article shows that in pre-colonial period it was difficult to determine ethnical boundaries in Tapanuli, particularly the Malay, Minangkabau, and Batak. However, after the Dutch government expanded its expansion to this region, the ethnical boundaries began to form and the differences among them became apparent. Ethnic segregation policy implemented by the Dutch and its support to the Batak ethnic group and the Christian obviously had formed and changed the awareness of ethnic identity among Batak and Malay people. In the early 20th century, the colonial government featured and strengthened the ethnic identity awareness in Batak community.
\end{abstract}

Keywords: colonial government, ethnical identity, Minangkabau, Malay, Batak, Tapanuli.

\section{INTRODUCTION}

The term "ethnic identity" is often used interchangeably with ethnicity. Both refer to an effort or a step of self-identifying and the feeling of becoming part of a wider group than family group or a chain of recognized people (Perret, 2010:14). Erikson (2002) identifies ethnicity as social relationship among groups that consider themselves different in culture from other group members.

Social relationship between ethnic groups generally based on economy and political existence with changeable manner. Therefore, ethnic boundaries as ethnic identity symbol that is intentionally created by ethnic group always change as well. This argument is in line with Perret's opinion (2010:17) that an individual never stops forming and reforming his group identity and his own identity by suggesting cultural characteristics or cultural boundaries which are possible to be adjusted to a particular social situation.

Perret opinion is very much influenced by instrumental approach that consider ethnic identity as a tool. It is in the contrary to primordialist point of view that considers ethnic identity that is formed by genealogic bound and culture has strong root and is not affected by anything due to the ethnic group senses of being satisfied psychologically (Colombijn, 2002:9). Primordialist approach is very much rejected by anthropologists and historians (Eriksen, 2002; Barth, 1988; Perret, 2010; Andaya, 2002) because it is considered viewing ethnic identity boundaries as something fixed and does not change through time. It differs from instrumental approach that views ethnicity 
as a tool able to change by economic, social and politic interest.

Conservative and instrumental views appearance in studying ethnicity is in fact caused by research time and space differentiation. In traditional society when economic and political interest are not dominant, the primodialist approach might be correct because the genealogy and cultural values are more important than economic value; meanwhile modern society (urban) tends to use ethnic identity as a tool to obtain materials, social status, and political sources. Therefore, the constructive approach by Frederick Barth (1988) that views ethnic boundaries as something that is created seems proper to be used to study the forming of ethnic identity in Tapanuli. It means that ethnic identity is created by particular ethnic groups, both due to particular importance and genealogic reason.

In Nusantara ethnic history, the Malay community is a good example of how an ethnic community continuously changes its ethnic identity. In 16th century, Malay people occupied important position in international trading world in Nusantara. The expansion of trading network and Islam formed Malay identity. However, since the Dutch conquered the port cities in Nusantara in 17th century, Malay and Minangkabau people were forced to re-identify their identity (Sutherland, 2001:397). Similar to Batak people, the Dutch colonial power expansion in Tapanuli hinterland in the early 19th century evoked ethnic identity awareness among Batak people community. This occurred because before the Dutch arrival, Batak was not recognized as ethnic category. Therefore, some experts such as Lance Castles and Perret assume that colonialism created Batak (Castle, 2001; Perret, 2010).

Various studies concerning ethnic in Nusantara show that ethnic identity is created and formed by groups with interests (Perret, 2010). In colonialism context, the Dutch is one of the groups that had interest in forming ethnic identity awareness in Nusantara. The Dutch wished to gain benefits as many as possible and the ethnic group encouragement to obtain authority and status are two important reasons of ethnic identity changes and formation.

On the other hand, ethnic groups in Nusantara also played a role in creating ethnic identity for their groups. This circumstance is suspected to differentiate one group to another. However, this matter is usually based on their genealogic similarity, so that assumption often appears from the group where ethnic identity already exist and it was handed down by their ancestors.

The forming of ethnic identity in a particular ethnic group that involved colonial government as the main actor can be viewed in the Malay, Minangkabau, and Batak people case in Tapanuli. Geographic condition (the combination between the coast and hinterland) and ethnic identity ambiguousness in Tapanuli made ethnic construction process in this region became more complex. Therefore, this paper desires to see how Malay and Batak defined are as ethnic identity, why the term of Malay Minangkabau emerged, and why colonialism considered having important role in forming ethnic identity awareness in Tapanuli. The discussion in this paper is focused on Tapanuli region in North Tapanuli.

\section{MINANGKABAU MALAY AND BATAK ETHNIC IDENTITY IN SUMATRA}

Malay concept has long been a debate among the historians and anthropologists. However, deep analysis concerning Malay world and categorization already made by experts leave some questions. From various literatures that discuss Malay, they imply that everyone is able to become Malay (Reid, 2001), so that it can be said that everyone is able not to become Malay. A good understanding concerning Malay concept will help us to understand the reality around Malay world.

Timothy P. Barnard (2001:1) suggests that Malay people are those who speak Malay, follow Malay tradition and Moslems. This definition is simple and it is easy for everyone to identify someone as a Malay person. However, in reality it is very difficult to categorize and to understand ethnic identity. This matter is admitted by Barnard himself $(2001: 1)$ that there are complicated problems concerning identity issues because the identity is an aspect that developed from every individual and group, and to identify ethnic group will involve religion, linguistic and social issues negotiation. Anthony Reid's study (2001:300) shows that identifying ethnic identity requires 
core political negotiation and state intervention, especially in the countries that possess similar tradition, such as Malaysia, Indonesia and Brunei.

Tradition similarity in particular ethnic community is an aspect enabling to unite them in one cause. However, if they are faced with different interests, the ethnic community will search differences in their commonalities, so that it is possible for them to form separate identity. This reality later encouraged Anthony Reid (2001) to analyze in deeper manner concerning the origin of Malay issues in Nusantara.

In 12th century, an Arabic geographer, Edrisi, stated that Malay was a huge island from South Asia that filled with gold, spices, and elephants. Some Chinese sources mention more specifically, namely a kingdom in the north of Sriwijaya. The more detail information about Malay is obtained in the books of Pararaton and Negarakargama that explain about Pamalayu expedition to conquer the Great Kingdom of Sumatra Malayu in 1275 by King Kertanegara from Singasari. However, at the moment apparently Malay does not exist in Sriwijaya that was claimed to be Palembang, but in Jambi (Reid, 2001:297).

In pre-colonial period, in Negarakartagama the entire Malay land is stated to belong to Minangkabau Kingdom; this kingdom was located under equator line, behind the hill formation in the west and almost in the middle of Sumatra Island (Marsden, 2008:305-306). When Sumatra Island was visited by European seamen for the first time, Minangkabau Kingdom was degrading. It was caused by the large political influence of kings of Aceh, Pedir, and Pasai in that period although they admitted that their authorities were originated from king of Minangkabau whom they respected. One of the kings from Aceh claimed Minangkabau west coast because that area was given as a wedding gift. This covered the entire west coast to Bengkulu or Selebar to the south. However, the area claimed by the king of Aceh only reached Padang to the south. At the end, the area belonging to him only reached Barus (Marsden, 2008:309).

Minangkabau kingdom as a symbol and source of authority in Sumatra has causing the assumption that Malay people who migrated from Sumatra to Semenanjung are from Minangkabau. Indeed, physically there are no differences between Malay people and Minangkabau people because both are from proto Malay. From the language aspect, there are similarities between Malay and Minangkabau languages. The differences simply lay on the dialect and the use of vocal alphabet /a/ and /o/ at the words' end. This was later lead to another assumption from Loeb (2013) that Minangkabau language was the primary language of Malay language, so that even Minangkabau people can be called Malay people (Marsden, 2008:40).

The inseparable identity of Malay and Minangkabau can be viewed from the efforts of Malay kings in Sumatra to identify themselves as the descendants of Pagaruyung rulers (the capital city of Minangkabau), such as Raja Siak and Barus (Barnard, 2001:334; Drakard, 2003). In Hikayat Siak it is mentioned that King of Siak, Raja Kecik had established a nation and its people were called Malay Minangkabau people. The term Minangkabau is used to describe Siak troops in some following pages of the text (Barnard, 2001:334). Likewise, in Sejarah Raja-raja Barus, particularly in Hilir chronicle (Tuanku Batu Badan History) it is mentioned that Pagaruyung was declared as the kingdom's source and the honor that shine on all the kings in Perca island (Sumatra), the descendants of Pagaruyung and who observedsyara' law.Raja Hilir in Barus is considered as one of descendants of Minangkabau King in Tarusan who left his residence due to the conflict with his father, Sultan Muhammad Syah (Drakard, 2003:33).

Even though there are many studies showing that Minangkabau is a part of Malay world, in the research about Minangkabau, particularly the history and its literature are separated one to another. According to Drakard (2003:15) Malay works that are originated from the west coast of Sumatra have not received attention yet. West Sumatra literature usually intended to Minangkabau literature was often written in Minangkabau dialect and is usually performed as kaba, tambo, or law. Furthermore, Drakard explains that the works often follow particular pattern and are concentrated on themes that have connection with social organization of Minangkabau mountain area. On the other hand, literary works that were produced by Minangkabau people who had travelled to west coast and produced literature in Malay language are not 
considered as part of Minangkabau literature. In fact, according to Voorhoeve (in Drakard, 2003) the border between Minangkabau and Malay literature is obviously unclear.

The unclear differences between Minangkabau and Malay literature correlate with the identity of both ethnic groups. However, Marsden, a British colonial officer in Sumatra said that if one wished to find out someone else's ethnic group, they should see how they legitimate their ethnicity (Marsden, 2008:42). Therefore, the ethnic boundaries suggested by Barth (1988) are no longer applicable. This matter is viewed in Hikayat Siak when a prince is exiled and accepts an invitation to join Minangkabau group of Palembang origin. However, one of the princes refuses it by saying that they are from the sea and not from the upper land (Barnard, 2001:335). In spatial context, sea and coast areas are spaces that always relate to Malay. They are parts of coast civilization (Vickers, 2009).

The unclearness and the variety of Malay become the characteristics os Malay identity. This matter is different from Batak ethnic identity that is more developed and has a clear origin. Batak people circle developed the myth about a center called Toba in the south of the lake that is accepted by every Batak person as the place of origin. They later spread and formed ethnic sub-group. According to Lance Castles research (2001:2) in Tapanuli, he found five sub-groups of Batak ethnic groups, namely Batak Toba, Batak Dairi, Batak Karo, Batak Simalungun, and Batak Mandailing. Among those subgroups there is a belief that they have genealogic unity that is called clan that becomes kinship bond symbol of one group with another (Vergouwen, 2004:6).

Batak ethnic group inhabit Tapanuli's certain place from which Batak Toba was originated. The area is considered as Batak ethnic group center. According to his research on Society and Customary Law of Batak Toba, Vergouwen (2004:7) suggests that Batak people considered themselves as descendents of Batak king from Pusuk Buhit Mountain in the west of Lake Toba. Vergouwen views about Batak ethnic origin is supported by genealogic research carried out by Castles (2001:3) towards Batak ethnic group. This study clearly shows emigrations of Batak people from Lake Toba surrounding to the area that at present is known as Tapanuli.

According to Batak historical sources, particularly the ones written by foreign researchers show two definitions of the most basic and dominant characteristics about Batak ethnic group. First, Batak ethnic group is always seen as cannibalistic group. A set of historical sources collected by Perret (2010:55-59) explain similar issue. According to Perret, Nico de' Conti is the first European man who used the term Batak that related to a population with cannibalism and who were fond of fighting with each other. Later on, Perret explains that in 1563 Joao de Barros reused the term Batak and mention Batak ethnic group as the wildest cannibals who were fond of fighting and they inhabited a part of an island facing Melaka. Among historical sources gained by Perret, Chinese sources are considered as the most dramatic sources because they describe the way Batak people ate human flesh. Guillot (2002:4) also explains that he found sources that described people living surrounding Barus as not human; they were tailed beasts.

Second, the definition concerning Batak ethnic group that is always present in historical sources is that the ethnic group refused Islam and ate swine. Batak rejection on Islam is narrated in Barus Kings tale as follow:

"...finally he turned into the inland area and visited Silindung, Bakara, and Pasaribu areas in Batak land. In Silindung, he has asked to become king. He refused, but made loyalty compromise with the people and showed four people as his representatives. In Bakara happened the similar condition, and there he lived in a moment as king. Meanwhile, he married to a daughter of the previous king who introduced Islam, even though many of the people did not embrace the religion. When he left the place, his wife from Batak did not come along. She was pregnant with baby boy that according to Sultan Ibrahim must be named Singa Maharaja. That boy will rule the entire area. In Pasaribu Sultan Ibrahim was welcomed and honored by the same manner and he made loyalty compromise to the people of Pasaribu." (Drakard, 2003:34) 
The excerpt from a tale above does not simply imply Batak people's unwillingness to embrace Islam, but shows equal relationship pattern between Batak ethnic in inland area, particularly in Toba area with the coast ruler (Sultan Ibrahim). The reason Batak people refused Islam apparently was caused by the fear that Islam would change their tradition, habit, and political position.

Batak people's habit to consume swine was contradictive to Islam. In fact, according to Vergouwen (2004:25-27), in Batak society, swine is not simply the food, but has symbolic meaning that shows social structure and belief. In Batak ethnic group there is sapanganan dalu (swine) ceremony; it is a sacrifice ceremony involving members of agnata group (every male relatives from father side) from six generations and different huta (kampong). In the ceremony, they will slaughter swine and cook it according to a particular order. The meat served for the ceremony must be cooked along with the blood in order for those who eat it will have brighter skin and each of the meat pieces is eaten in accordance with their social structure in Batak society. In relation to Batak people in eating swine habit, Marsden (2008:346) explains that in fact they are more pleased to eat the un-slaughtered swine because it has better taste so that they do not hesitate to eat dead swine meat. This matter is surely contradictive to Islam that forbids its believers to eat swine, blood, and corpse.

Batak people in the inland area of Tapanuli also consider that by becoming Islam would make them surrender to the rulers in the coast (Malay). The relation between Batak people and the rulers in the coast was mutual. Batak people gave tribute to the coast ruler and in return they obtained safety guarantee from the kings in the coast. Therefore, Batak people did not bow to any authority from outside of their region. As Castles says (2001), they did not have state and are $\mathrm{n}$ separated from the authority center in Sumatra, such as Aceh and Siak. Batak people are known as ethnic group that are free and are not fond of being suppressed. At least, this condition existed until before the colonists' arrival. This uncomfortable and threatening situation would make them act rough and uncontrolled. Therefore, it was not a surprise that they often involved in conflict, both with their own group members or other ethnic groups.

\section{THE CREATION OF ETHNIC BOUNDARIES IN TAPANULI BY THE COLONISTS}

Culture, religion, and geographic boundaries existence between Batak people in the hinland and Malay people in the coast area became the basis for colonial government to categorize ethnic groups in Sumatra's west coast. They tookan advantage of the ethnic differences for their economic and political interest. The mutual relation between Batak and Malay people changed into rivalry. Negative perspective toward Batak ethnic group and their education overtaking made Batak people become more advanced than Malay ethnic group. The government officers and missionaries played important roles in this process. They opened the door of Batak land for advancement.

In the early stage, colonial government made ethnic maps in Sumatra and categorized the entire Tapanuli people as Batak people, except for Malay people who were located in the coastal area (Voorhoeve via Abdullah, 1990:281). However, during colonial period not everyone categorized as Batak is in Tapanuli, Batak Simalungun and Karo that were administratively outside Tapanuli; it is under Sumatra East Coast government (Enda Boemi, 1925:2-3). On the contrary, the regions that were administratively included in Tapanuli is partly occupied by Coastal Malay people, such as Sibolga, Natal, and Barus. However, if examined in genealogic manner, most of Malay people in the coast regions of Tapanuli were Batak descendants. Intermarriage between ethnic groups and Islam heavy influence on Batak people circle in the coast made them become Malay people. Gradually their Batak identity became unclear and they were unwilling to be called Batak.

For the colonial government and the missionaries Batak people's unclear ethnic identity in the coast was considered a drawback. It would have been better for them if Batak people had remained as they had were so that they would be able to expel Islam's influence out of Tapanuli. The missionaries brought Batak people that already became Moslems into Tapanuli inhabited by Christianized Batak people in. This evoke danger from anti-Padri Muslims that became colonial ally in West Sumatra (Castles, 2001:18).

In 1824, two British co missionaries, Richard Burton and Nathaniel Ward, entered Batak hinland 
in Tapanuli. However, after a few days in the area, they realized that Batak people did not like their presence. 10 years later, in 1834, two American preachers experienced tragic fortune after attempting to spread Christian belief in Batak people circle (Reid, 2010:212; Keuning, 1990:300). Various incident experienced by missionaries in Tapanuli clarified Batak people primitive attitude seen from the colonists' viewpoint.

After the death of two American missionaries in Tapanuli inland there was no missionary mission in almost 13 years in this area. However, on December 8th 1847 Netherlands Bible Society pointed one linguist, Herman Neubronner van der Tuuk to learn Batak language and translate the Bible into Batak language. The language problem that had possibly been experienced by the previous missionaries encouraged the Netherlands Bible Society to send van der Tuuk to Tapanuli. Through a long journey finally in the early 1851 van der Tuuk arrived in Sibolga (the capital residence of Tapanuli). He found that Batak language in Sibolga had been influenced by Malay language. He lived in Barus in 1853 and collected materials and created a brilliant description about Batak language that was published in the Netherland after 1858 (Grinjs, 354-355).

During his stay in Tapanuli van der Tuuk criticized the Dutch colonial government because they gave the opportunity to Islam to grow in Tapanuli. This condition feared by van der Tuuk that it would obstruct the colonists' interest. However, the Dutch government and missionary must have an ally to expand their occupied area and to make Christianity preaching easier. Batak people in the hinland were still certain that their traditional belief was the best ally to confront Islam. According to Van der Tuuk, the best measure to make Batak people join the alliance is by Christening them and maintained their characteristics so that the differences between Malay people (including Batak Islam people who has become Malay) and Batak people would become clear. Lance Castles considers van der Tuuk anti-Islam stance was partly based on imperialist consideration and national pluralism (Castles, 2001:19).

The colonial government did not disagree with van der Tuuk's view, but Christening Batak people in Tapanuli seemed too late. If it had been implemented in 1849 , probably a lot could have been achieved. Islam had been followed by many people, so that it was difficult to obstruct them, particularly in the coastal area and south part of Tapanuli (Mandailing). The last hope was only Batakladen, Tapanuli area that had not been touched by Islam. At the end of 19th century, the wedge policy between Islam area (Aceh and Minangkabau) and Christian (North Tapanuli) was implemented to obstruct the entering of Islam in peaceful manner (Castles, 2001:20). Geographically, Tapanuli area was in between Islam spread areas, Aceh in the north and Minangkabau in the south (Nur, 2011:315).

Van der Tuuk spirit to re-feature Batak people characteristics obviously had inspired Western researchers to start studying Batak. Starting in the second half of 19th century, physical characteristics and myths of its origin were collected to give early materials to western researchers. The myth existence is in fact considered by the western researchers were able to legitimate the point of view on ethnic differences between Batak people in the inland and Malay people in the coast.

In forming ethnic identity awareness among Batak people the Dutch obviously did not simply collect the myths relating to their origin, but also creating myths about Batak and Malay people's characteristics. On one side, Batak people were diligent, energetic, economical, outspoken, honest, clever, and thirsty for learning. On the other side, Malay people were lazy, weak, hypocritical, suspicious, and ignorant about the future (Alatas, 1988). In political point of view, the foreign observers distinguish between centralized Malay Coast kingdoms ruled by a king and the plentiful of democratic people organization in Batak society (Perret, 2010:67).

The existence of Batak people as one united ethnic group was strengthened by various studies on Batak ethnic tradition. One of the major research findings that became important reference in understandingBatak ethnic group is a book by J.C. Vergouwen (2004) entitled Masyarakat dan Hukum Adat Batak Toba (Society and Traditional Law of Batak Toba). This book was first published in Dutch language in 1933. The text materials were collected by Vergouwen from 1927 when he was on duty in North Tapanuli. He was assigned to 
compose one report concerning how native justice system worked in the area and it was completed in 1930. The materials were absolutely complete so that he was successful in writing a book about society life, native beliefs and tradition ideas, as well as tradition law of Batak Toba people.

The Dutch colonial efforts to grow ethnic identity awareness in Batak people circle obviously gave significant impacts. The growth of myths about Batak people as one large united ethnic group had grown self-confidence for them to increasingly confirm ethnic symbols they had. Before the colonists' arrival, Batak people were unwilling to show their self-identity in the form of clan, however, after they followed Christianity they were no longer ashamed to label their clan, a self-unifying and distinctive symbol differing them from other groups outside Batak.

Batak people's ethnic identity was increasingly stronger in Tapanuli in compliance with discriminative politics implemented by the Dutch. The Dutch colonial government divided people settlement based on ethnicity and appointed local chiefs to be in charge of kampongs in Sibolga, such as Pesisir, Nias, Mandailing, Melayu, Batak, Minangkabau (Panggabean, 1995:65). Each ethnic group had their own ethnic identity symbol, such as clan, language, clothing, religion, and art. Through this symbolization, they were able to see the boundaries among the ethnic groups who were present in city space, both physical and non-physical, such as street, office, markets, harbors, housing, organization and governance (Nur, 2006). In this context in implicit manner there was particular ethnic domination in every city space. For example, Batak people's involvement in the governance and Minangkabau people that were active in the market due to their role in commerce sector (Asnan, 2007; Nur, 2006). Space discrimination based on ethnicity seemed very much primordialistic, stereotyping, and tended to be related to psychological characteristics. For instance, the domination of Batak people encouraged them to get involved in the governance (Pelly, 1994).

During colonial period, space discrimination and segregation based on ethnicity was intentionally maintained by the Dutch as the separator line between ethnic groups (Tanjung, 2006). During Japanese occupation, they tried to eliminate ethnic discrimination especially in education field. However, the short period did not very much change the order that had long been built by the Dutch. Even in other colonial cities, ethnic discrimination would fade in the independence period, but in the Sumatra West coastal area, the ethnicity still colored every city area until the independence. Batak people's expansion that continued to increase from the hinland area to Sibolga in the independence period strengthened Batak ethnic primordialists in fighting for city space (Panggabean, 1995:181; Cunningham, 1958).

\section{CONCLUSION}

The Malay Minangkabau and Batak people ethnic identity in Tapanuli during pre-colonial period was full of ambiguousness. Generally, Malay people in Tapanuli coast were from Minangkabau. However, they were later called Malay people. Geographic borders were often used as ethnic boundaries. The coastal area was considered as part of Malay ethnic identity. However, in the Tapanuli case, ethnic groups that occupied the coast were between two identities, namely Malay and Minangkabau, so that in ethnicity map Tapanuli coastal region is called Minangkabau Malay area. The ethnic identity ambiguousness was also experienced by Batak people, particularly in the period before colonial expansion in Tapanuli in the early 19th century. Batak people were unwilling and ashamed to be called Batak because they were considered cannibals and uncivilized. They were more comfortable to be called Malay and did not use their clan which was an identity symbol for them.

The appearance of ethnic identity awareness in Batak people had just begun after the Dutch economic and politic expansion in Sumatra. The ethnic identity ambiguousness in Batak people for the Dutch was considered as an obstacle to extend the Dutch's authority in Tapanuli. Therefore, this ethnic identity chaos was created by the Dutch by making ethnic categories that were permanent in administration and Christianized Batak people. For the colonists Christianitywould be a tool to separate between Malay and Batak people in Tapanuli. In order to develop self-confidence among Batak people the researchers who were 
also colonial officials collected various myths about the origin of Batak people and implemented ethnic discriminative policy towards the native inhabitants.

\section{BIBLIOGRAPHY}

Alatas, S.H. (1988). Mitos Pribumi Malas: Citra Orang Jawa, Melayu dan Pilipina dalam Kapitalisme Kolonial. Jakarta: LP3ES.

Abdullah, Taufik (ed). (1990). Sejarah lokal di Indonesia. Yogyakarta: Gadjah Mada University Press.

Andaya, Leonard, Y. (2002). "The Trans-Sumatra Trade and the Ethnicization of the Batak". Bijdragen : Tot de Taal, Land - en Volkenkunde, Vol.158, No.3. pp. 367-409. Published by: KITLV, Royal Netherlands Institute of Southeast Asian and Caribbean Studies. From : http://www. jstor.org/stable/27865844.

Asnan, Gusti. (2007). Dunia Maritim Pantai Barat Sumatra. Yogyakarta: Penerbit Ombak.

Barth, Frederik. (1988). Kelompok Etnik dan Batasannya. Jakarta: Penerbit Universitas Indonesia.

Barnard, Timothy P. (2001). "Text, Raja Ismail and Violence: Siak and the Transformation of Malay Identity in the Eighteenth Century: Journal of Southeast Asian Studies". Vol. 32. No. 3. October, Published by: Cambridge University Press on behalf of Department of History. National University of Singapore.

Cunningham, Clark E.( 1958). The Postwar Migration of the Toba Bataks to East Sumatra. New Haven:YaleUniversitySoutheastAsiaStudies.

Colombijn, Freek and Aygen Erdentug. (2002). Urban Space and Ethnicity dalam Aygen Erdentug and Freek Colombijn (ed.), Urban Ethnic Encounters; The Spatial Consequences. London and New York: Routledge.

Castles, Lance. (2001). Kehidupan Politik Suatu Keresidenan di Sumatra: Tapanuli 1915-1940. Jakarta: KPG.

Drakard, Jane. (2003). Sejarah Raja-raja Barus: Dua Naskah dari Barus. Jakarta : Gramedia Pustaka Utama dan Ecole Francaise d'Extreme-Orient.

Eriksen, Thomas Hylland. (2002). Ethnicity and Nationalism. London: Pluto Press.

Enda Boemi, Alinoeddin. (1925). Het Grondenrecht in de Bataklanden (Tapiannaoeli, Simeloengoen, en het Karoland). Leiden: Eduard Ijdo.

Guillot, Claude. (2002). Lobu Tua, Sejarah Awal Barus.
Jakarta: Yayasan Obor Indonesia.

Grijns, C.D. (1996). "Van der Tuuk and the Study of Malay". Bijdragen tot de Taal-, Landen Volkenkunde. Deel 152. 3de Afl., pp. 353-381 .Published by: KITLV, Royal Netherlands Institute of Southeast Asian and Caribbean Studies. From. http://www.jstor.org/ stable/27864774.

Keuning, J. (1990). Batak Toba dan Batak Mandailing, dalam Taufik Abdullah (ed). Sejarah lokal di Indonesia. Yogyakarta: Gadjah Mada University Press.

Loeb, Edwin M. (2013). Sumatra, Sejarah dan Masyarakatnya. Yogyakarta: Penerbit Ombak.

Marsden, William. (2008). Sejarah Sumatra. Jakarta: Komunitas Bambu.

Nur, Aslam. (2011). "Ulama dalam Dinamika Sosial dan Budaya Masyarakat Aceh di Awal Abad ke Dua Puluh Satu". Jurnal Humaniora. Vol. 23. No. 3 Oktober. 315- 325.

Nur, Mhd.( 2006). "Bandar Sibolga di Pantai Barat Sumatra", (Tidak diterbitkan). Jurusan Sejarah, Fakultas Ilmu Budaya Universitas Indonesia.

Pelly, Usman. (1994). Urbanisasi dan Adaptasi; Peranan Misi Budaya Minangkabau dan Mandailing. Jakarta: LP3ES.

Pangabean, H.A. Hamid. (1995). Bunga Rampai Tapian Nauli. Jakarta: PT Nadhilah Ceria Indonesia.

Perret, Daniel. (2010). Kolonialisme dan Etnisitas; Batak dan Melayu di Sumatra Timur Laut. Jakarta: Kepustakaan Populer Gramedia.

Reid, Anthony. (2001). “Understanding Melayu (Malay) as a Source of Diverse Modern Identities": Journal of Southeast Asian Studies. Vol. 32. No. 3 .Oct. Published by: Cambridge University Press on behalf of Department of History, National University of Singapore. . (2010). Sumatra Tempo Doeloe: dari Marco Polo sampai Tan Malaka. Jakarta: Komunitas Bambu.

Sutherland, Heather. (2001). "The Makassar Malays: Adaptation and Identity. c. 1660-1790: Journal of Southeast Asian Studies. Vol. 32. No. 3 .Oct. Published by: Cambridge University Press on behalf of Department of History, National University of Singapore

Tanjung, Ida Liana.(2006). "Modernitas dan Dekolonisasi Perkotaan Sumatra Selatan Abad ke-20”, (Unpublished Thesis). Jurusan Sejarah 
Fakultas Ilmu Budaya, Universitas Gadjah Mada, Yogyakarta.

Vickers, Adrian. (2009). Peradaban Pesisir; Menuju
Sejarah Budaya Asia Tenggara. Denpasar: Pustaka Larasan.

Vergowen, J.C. (2004). Masyarakat dan Hukum Adat Batak Toba. Jakarta: Pustaka Azet. 